\title{
O papel pastoral da família cristã no atual processo evangelizador
}

\author{
Orientador: Prof. Abimar Oliveira de Moraes \\ Pesquisadora: Bruna Martins Ferreira dos Santos \\ Fonte: Voluntária
}

\section{Introdução}

Nesse segundo momento da Pesquisa nos detemos na Exortação Apostólica Amores Laetitia onde percebemos uma maior abertura ao diálogo para os diversos contextos de família na atualidade, onde nas diversas realidades encontramos novas configurações.

\section{Objetivos}

Através da leitura da Exortação, das posturas de acolhimento do Papa Francisco, notamos uma tentativa de abertura aos que se sentem fora da Igreja, que é sinal da presença do Ressuscitado no mundo. A proposta da pesquisa nesse segundo momento é destacar como a Exortação apresenta às famílias cristãs orientações permeadas pela misericórdia para atuar na evangelização nos dias atuais. 